\title{
STATISTICAL ANALYSIS OF TRIHALOMETHANES IN TREATED-WATER TANKS: SEASONALITY, LOCAL VARIABILITY AND CORRELATIONS
}

\author{
E. SMETI ${ }^{1,4, *}$ \\ S. SAMIOS ${ }^{1,2}$ \\ A. NIKOLAOU ${ }^{3}$ \\ S. GOLFINOPOULOS ${ }^{4}$ \\ T.D. LEKKAS ${ }^{2}$
}

\author{
${ }^{1}$ Athens Water Supply and Sewerage Company, \\ Quality Control Department, \\ 156, Oropou st., Galatsi, 11146 Athens, Greece \\ ${ }^{2}$ Department of Environmental Studies, Faculty of the Environment, \\ University of the Aegean, University Hill, 81100 Mytilene, Greece \\ ${ }^{3}$ Department of Marine Sciences, Faculty of the Environment, \\ University of the Aegean, University Hill, 81100 Mytilene, Greece \\ ${ }^{4}$ Department of Financial and Management Engineering, \\ University of the Aegean, Kountourioti 41, 82100 Chios, Greece
}

Received: $17 / 11 / 09$

Accepted: 28/06/10 *to whom all correspondence should be addressed: e-mail: e.smeti@fme.aegean.gr

\section{ABSTRACT}

Chlorine was accepted as an effective disinfectant for drinking water in early 1900s. Because of chlorination, chlorine has dramatically reduced the incidence of waterborne diseases. An unwanted side effect is the formation of harmful by-products upon chlorination. The most significant group of disinfection by-products formed during chlorination is the trihalomethanes (THMs).

In this reason, European Union initiated the maximum contaminant level (MCL) of total concentration of THMs to $100 \mathrm{Mg} \mathrm{L}^{-1}$. Because of this regulation, operational parameters of the WTP and raw water quality characteristics need to be studied in depth in order for THMs to be minimised. Statistical analysis is necessary for this purpose employing the parametric two-way ANOVA for the concentrations of chloroform $\left(\mathrm{CHCl}_{3}\right)$ and dichlorobromomethane $\left(\mathrm{CHCl}_{2} \mathrm{Br}\right)$ and the analysis of variance on data ranks of chlorodibromomethane $\left(\mathrm{CHClBr}_{2}\right)$ concentration. Chlorine dose, postchlorination, bromide levels, reaction temperature, reaction duration and dissolved organic carbon levels as well as $\mathrm{pH}$ of raw water, are the factors that affect the rate of THMs formation and the total THMs yield. Athens Water Supply and Sewerage Company (EYDAP SA), as the water supplier of a city with 3.5 million inhabitants, makes continuous attempts to improve water quality.

KEYWORDS: Disinfection by-products (DBPS), trihalomethanes (THMs), Water Treatment Plants (WTPS), ANOVA, correlations.

\section{INTRODUCTION}

Chlorine has been used as a disinfectant since 1908, and it is still widely used for this purpose. Its main advantages are disinfection effectiveness, relatively low cost, easy application compared with that of chlorine dioxide and UV and high oxidation potential. On the other hand, its reactivity with natural organic matter (NOM) and DBPs production such as trihalomethanes still remains one of its disadvantages. Various investigations of the past have been developed to correlate THMs formation with independent parameters of raw water that has been chlorinated. Raw water's Dissolved Organic Carbon (DOC) as well as bromide anions, chlorination temperature, chlorine dosage, postchlorination and detention time, chlorophyll a (Nikolaou et al., 1999) and pH of raw water are the measurable parameters, which influence the occurrence of trihalomethanes. Total Organic Carbon (TOC), DOC or UV-254 nm absorbance (Singer and Chang, 1989) instead of humic as well as fulvic constituents of organic matter are often measured and used in TTHMs predictive models (Gang et al., 2001). Bromides' levels determine the ratio of the three brominated species (Symons et al., 1993). The effect of ammonia on the applied chlorine dosage is shown only in predictive models where ammonia is present in raw water for chlorination (Dore et al., 1982). 
The aim of this paper was to study the parameters of $\mathrm{CHCl}_{3}, \mathrm{CHCl}_{2} \mathrm{Br}$ and $\mathrm{CHClBr}_{2}$ and the effects of seasonality (Cold period: October to March, and Warm period: April to September) and the specific nature of four water treatment plants of EYDAP (Athens Water Supply and Sewerage Company) on them. Water samples from reservoir tanks of four WTPs were collected on a monthly basis, over a 3-year period (20042006), and analysed for the aforementioned parameters. The untreated water for the two of the tanks (Menidi and Aspropyrgos) is from Mornos reservoir. The other two tanks (Galatsi 1 and Galatsi 2) are supplied by both Mornos and Marathon reservoirs whose ratio changes from time to time. Water quality and operational parameters were monitored at sampling points of the entrance in the water treatment plants (WTPs).

\section{MATERIALS AND METHODS}

THMs levels were monitored for three years after sampling from finished water reservoirs of four WTPS and bromide levels, $\mathrm{pH}$ and TOC were measured in raw water, and residual chlorine in reservoirs. Chorine dosage was registered instead of pre- and postchlorination levels. $\mathrm{pH}$ was measured by Metrohm pehameters, and residual chlorine by portable Hach chloriometers almost immediately after sampling. A Metrohm ionic chromatograph was employed for bromide determination and TOC was determined by a Shimadzu TOC analyser.

The method employed for the determination of THMs, Haloacetonitriles (HANs), Haloketones (HKs), Chloral Hydrate and Chloropicrin was a modification of 551.1 EPA method developed by Nikolaou et al. (2001) as it allows to extract them from drinking water quantitatively (Cancho and Ventura, 2005). Methylt-butyl ether (MTBE) is the primary extraction solvent. A $35 \mathrm{~mL}$ sample aliquot is extracted with $2 \mathrm{~mL}$ of MTBE after addition of $2.5 \mathrm{gr} \mathrm{Na}_{2} \mathrm{SO}_{4}$. One $\mu \mathrm{L}$ of the extract is then injected into a GC equipped with a fused silica capillary column and electron capture detector for separation and analysis. Procedural standard calibration is used to quantitate method analytes.

\section{STATISTICAL ANALYSIS}

Techniques of the two-way analysis of variance (two-way ANOVA) for each THM were used as appropriate ones to examine the effect of both seasonality and specific nature of every WTP. The influences of the season and specific technical characteristics were simultaneously tested to determine if they cause significant differences between treatment group means. For the parametric two-way analysis of variance for each variable, each group is assumed to have normal distribution and all groups are assumed to have the same variance.

The Shapiro-Wilks test was used to test the data for Normality. The Levene's test was used to test for homogeneity of variances across groups. In case of a statistically significant result of the Levene's test, the analysis of variance on data ranks was used instead of the classical ANOVA. Analysis of variance on data ranks is an "asymptotically distribution-free technique" which is more robust to non-normality, and resistant to outliers and non-constant variance, than is the two-way ANOVA without the rank transformation (Helsel and Hirsch, 2002). The data were ranked from smallest to largest and an analysis of variance was then performed on the ranks of the data. These tests determine whether the mean rank differs between treatment groups, rather than the mean. The mean rank is interpreted as an estimate of the median. Multiple comparison procedures on the ranks can then differentiate which groups differ from others. The multiple comparison tests compare all possible combinations of treatment group centers (means or mean ranks), ranking the centers in order to indicate which are similar or different from others.

The non-parametric Spearman rank correlation was used to test the relationship between the three THMs and other chemical parameters such as total organic carbon (TOC), chlorine dose $(\mathrm{dCl})$, bromide ( $\mathrm{Br}), \mathrm{pH}$ and temperature (Temp).

Statistical analyses were conducted using SPSS version 13.0 for Windows.

\section{RESULTS AND DISCUSSION}

Raw water originated, mainly, from Marathon and Mornos reservoirs. The concentrations of organic compounds in Marathon lake vary in high levels, in Mornos reservoir the organic content of water is lower and, often TOC is about $1.0 \mathrm{mg} \mathrm{L}^{-1}$. Also, $\mathrm{pH}$ is about 8.2-8.3 in Mornos reservoir, without further fluctuations and bromide levels, fairly steady to $0.010 \mathrm{mg} \mathrm{L}^{-1}$ about. Raw water temperature ranged from 8 to $16^{\circ} \mathrm{C}$, while $\mathrm{pH}$ varied from 7.9 to 8.4. The dose of chlorine (sum of pre- and postchlorination) was lying in the range of 1.0 to $2.1 \mathrm{mg} \mathrm{L}^{-1}$. 
Table 1. Descriptive Statistics for $\mathrm{CHCl}_{3}, \mathrm{CHCl}_{2} \mathrm{Br}$ and $\mathrm{CHClBr}_{2}$ per tank and season

\begin{tabular}{|c|c|c|c|c|c|}
\hline & Tank & Season & Mean & $\begin{array}{c}\text { Std. } \\
\text { Deviation }\end{array}$ & $\begin{array}{l}\text { Number of } \\
\text { samples }\end{array}$ \\
\hline \multirow{15}{*}{$\mathrm{CHCl}_{3}$} & Galatsi 1 & 1 cold & 8.57 & 3.13 & 21 \\
\hline & & 2 warm & 8.48 & 2.38 & 16 \\
\hline & & Total & 8.53 & 2.80 & 37 \\
\hline & Galatsi 2 & 1 cold & 9.09 & 2.64 & 19 \\
\hline & & 2 warm & 9.82 & 3.00 & 15 \\
\hline & & Total & 9.41 & 2.78 & 34 \\
\hline & Menidi & 1 cold & 12.72 & 2.84 & 21 \\
\hline & & 2 warm & 13.44 & 2.25 & 16 \\
\hline & & Total & 13.03 & 2.60 & 37 \\
\hline & Aspropyrgos & 1 cold & 12.85 & 2.33 & 19 \\
\hline & & 2 warm & 14.80 & 3.23 & 16 \\
\hline & & Total & 13.74 & 2.91 & 35 \\
\hline & Total & 1 cold & 11.05 & 4.38 & 80 \\
\hline & & 2 warm & 11.66 & 3.73 & 63 \\
\hline & & Total & 11.32 & 4.10 & 143 \\
\hline \multirow{15}{*}{$\mathrm{CHCl}_{2} \mathrm{Br}$} & Galatsi 1 & 1 cold & 4.93 & 1.42 & 21 \\
\hline & & 2 warm & 5.39 & 1.46 & 16 \\
\hline & & Total & 5.13 & 1.44 & 37 \\
\hline & Galatsi 2 & 1 cold & 5.20 & 0.98 & 19 \\
\hline & & 2 warm & 5.56 & 1.60 & 15 \\
\hline & & Total & 5.36 & 1.28 & 34 \\
\hline & Menidi & 1 cold & 3.76 & 1.06 & 21 \\
\hline & & 2 warm & 4.05 & 0.79 & 16 \\
\hline & & Total & 3.89 & 0.95 & 37 \\
\hline & Aspropyrgos & 1 cold & 3.60 & 0.63 & 19 \\
\hline & & 2 warm & 3.65 & 0.80 & 16 \\
\hline & & Total & 3.62 & 0.70 & 35 \\
\hline & Total & 1 cold & 4.37 & 1.26 & 80 \\
\hline & & 2 warm & 4.65 & 1.45 & 63 \\
\hline & & Total & 4.49 & 1.35 & 143 \\
\hline \multirow{15}{*}{$\mathrm{CHClBr}_{2}$} & Galatsi 1 & 1 cold & 2.98 & 1.22 & 21 \\
\hline & & 2 warm & 3.40 & 1.29 & 16 \\
\hline & & Total & 3.16 & 1.25 & 37 \\
\hline & Galatsi 2 & 1 cold & 3.00 & 1.22 & 19 \\
\hline & & 2 warm & 3.14 & 1.36 & 15 \\
\hline & & Total & 3.06 & 1.27 & 34 \\
\hline & Menidi & 1 cold & 0.78 & 0.22 & 21 \\
\hline & & 2 warm & 0.73 & 0.13 & 16 \\
\hline & & Total & 0.76 & 0.18 & 37 \\
\hline & Aspropyrgos & 1 cold & 0.54 & 0.15 & 19 \\
\hline & & 2 warm & 0.56 & 0.16 & 16 \\
\hline & & Total & 0.55 & 0.15 & 35 \\
\hline & Total & 1 cold & 1.83 & 1.45 & 80 \\
\hline & & 2 warm & 1.94 & 1.61 & 63 \\
\hline & & Total & 1.88 & 1.52 & 143 \\
\hline
\end{tabular}

The two Galatsi WTPs supply water to nearly one and a half million people. Marathon as well as Mornos reservoir are the significant bodies of fresh water in Athens processed by Galatsi WTPs. Major parts of the process include coagulation, flocculation, sedimentation and sand filtration and the flow of water is from the entrance of the plant to flocculation and then, sedimentation tanks, to sand filtration beds and, 
finally to finished water reservoir. Prechlorination is applied before coagulation process and postchlorination is applied before the input of finished water in the distribution system. Chlorination points are the same in the two Galatsi WTPs but Galatsi 2 has no flocculation tank; coagulation, flocculation and sedimentation are accomplished in the sedimentation tank. Menidi facilities are also divided in two section (Menidi 1 and Menidi 2). Both sections are supplied exclusively by Mornos reservoir but there is also a difference in plants' facilities. In this article, only Menidi 2 monitoring is examined. Aspropyrgos treatment plant is also supplied exclusively by Mornos reservoir. In Aspropyrgos WTP, coagulation, flocculation and sedimentation are accomplished in the same circular tank.

Differences of the flow to each WTP separately from day to day as well as WTPs specific technical characteristics mentioned above add another parameter that determines the final level of THMs in reservoirs; this of detention time i.e. contact time of chlorine with processed water from the time of prechlorination till the reservoir. Long reaction time influences the formation of larger THMs concentrations but the decomposition of other DBPs (Golfinopoulos and Nikolaou, 2005). For example Aspropyrgos WTP has lower contact times and inflows than Menidi and the two Galatsi systems and detention time is about 12 hours when raw water inflow and process is $150,000 \mathrm{~m}^{3} \mathrm{~d}^{-1}$. When water inflow rises the contact time decreases in the coagulation-flocculation-sedimentation tank and finished water reservoir of Aspropyrgos WTP, so detention time from prechlorination till water inflow to reservoir ranges from two to four hours but usually is three hours.

The maximum value of the sum of the four THMs was $27.89,27.77,24.7025 .40 \mu \mathrm{g} \mathrm{L}^{-1}$ for Galatsi 1 , Galatsi 2, Menidi and Aspropyrgos tanks respectively, far below the MCL for European Union which is $100 \mu \mathrm{g} \mathrm{L}^{-1}$. A preliminary two-way ANOVA on the sum of the four THMs, with "tank" and "season as factors, resulted in non statistical significance at the 0.05 level ("Tank": $F(3,135)=0.40, p$-value $=0.75$; "Season": $F(1,135)=3.33$, p-value $=0.070$; Interaction "Tank ${ }^{*}$ Season": $F(3,135)=0.14$, p-value $=0.93$. The maximum value of $\mathrm{CHBr}_{3}$ was 1.15, 0.94, 0.06 and lower than $0.04 \mu \mathrm{g} \mathrm{L}^{-1}$ for Galatsi 1, Galatsi 2, Menidi and Aspropyrgos tanks respectively.

Table 1 presents descriptive statistics for each one of the three THMs per tank and season. The ShapiroWilks test for Normality was not significant at the 0.05 significance level for each combination of tank and season (Table 2).

Table 2. Shapiro-Wilk Tests of Normality $\mathrm{CHCl}_{3}, \mathrm{CHCl}_{2} \mathrm{Br}$ and $\mathrm{CHClBr}_{2}$ per tank and season

\begin{tabular}{lllrrr}
\hline Tank & & season & Statistic & df & p-value \\
\hline Galatsi 1 & $\mathrm{CHCl}_{3}$ & 1 cold & 0.954 & 21 & 0.40 \\
& & 2 warm & 0.968 & 16 & 0.80 \\
& $\mathrm{CHCl}_{2} \mathrm{Br}$ & 1 cold & 0.912 & 21 & 0.06 \\
& & 2 warm & 0.909 & 16 & 0.11 \\
& $\mathrm{CHClBr}_{2}$ & 1 cold & 0.911 & 21 & 0.06 \\
& & 2 warm & 0.914 & 16 & 0.14 \\
\hline Galatsi 2 & $\mathrm{CHCl}_{3}$ & 1 cold & 0.936 & 19 & 0.23 \\
& & 2 warm & 0.945 & 15 & 0.44 \\
& $\mathrm{CHCl}_{2} \mathrm{Br}$ & 1 cold & 0.950 & 19 & 0.40 \\
& & 2 warm & 0.933 & 15 & 0.30 \\
& $\mathrm{CHClBr}_{2}$ & 1 cold & 0.936 & 19 & 0.22 \\
& & 2 warm & 0.976 & 15 & 0.94 \\
\hline Menidi & $\mathrm{CHCl}_{3}$ & 1 cold & 0.976 & 21 & 0.86 \\
& & 2 warm & 0.967 & 16 & 0.79 \\
& $\mathrm{CHCl}_{2} \mathrm{Br}^{2}$ & 1 cold & 0.948 & 21 & 0.31 \\
& & 2 warm & 0.931 & 16 & 0.25 \\
& $\mathrm{CHClBr}_{2}$ & 1 cold & 0.981 & 21 & 0.93 \\
& & 2 warm & 0.960 & 16 & 0.66 \\
\hline Aspropyrgos & $\mathrm{CHCl}_{3}$ & 1 cold & 0.974 & 19 & 0.85 \\
& & 2 warm & 0.935 & 16 & 0.30 \\
& $\mathrm{CHCl}_{2} \mathrm{Br}$ & 1 cold & 0.912 & 19 & 0.08 \\
& & 2 warm & 0.964 & 16 & 0.74 \\
& $\mathrm{CHClBr}_{2}$ & 1 cold & 0.948 & 19 & 0.36 \\
& & 2 warm & 0.952 & 16 & 0.53 \\
\hline & & & & &
\end{tabular}


Table 3. Levene's Test of Equality of Error Variances ${ }^{a}$

\begin{tabular}{lrrrr}
\hline & $\mathrm{F}$ & $\mathrm{df1}$ & $\mathrm{df2}$ & p-value \\
\hline $\mathrm{CHCl}_{3}$ & 0.59 & 7 & 135 & 0.76 \\
$\mathrm{CHCl}_{2} \mathrm{Br}$ & 1.75 & 7 & 135 & 0.10 \\
$\mathrm{CHClBr}_{2}$ & 10.43 & 7 & 135 & $<0.001$ \\
$\mathrm{RANKS}$ of $\mathrm{CHClBr}_{2}$ & 1.01 & 7 & 135 & 0.43 \\
\hline
\end{tabular}

${ }^{\mathrm{a}}$ Tests the null hypothesis that the error variance of the dependent variable is equal across groups

The Levene's test for homogeneity of variance was significant at the 0.05 significance level only for $\mathrm{CHClBr}_{2}$ (Table 3). Therefore, the techniques which were used as appropriate ones to examine the effect of both the seasonality and the nature of WTP on THMs were the parametric two-way ANOVA for the concentrations of $\mathrm{CHCl}_{3}$ and $\mathrm{CHCl}_{2} \mathrm{Br}$ and the analysis of variance on data ranks of the $\mathrm{CHClBr}_{2}$ concentration.

The statistical analysis pointed out that the effect of the nature of WTP is statistically significant (at the 0.05 significance level) for the concentration of each one of the three THMs (Table 4). None of the THMs was statistically significantly influenced by the season at the 0.05 significance level. No significant interaction between season and sampling tank was observed as well.

Table 4. Summary of two-way Analysis of variance for $\mathrm{CHCl}_{3}, \mathrm{CHCl}_{2} \mathrm{Br}$ and $\mathrm{CHClBr}_{2}$

\begin{tabular}{lcrr}
\hline & $\begin{array}{c}\text { Degrees of } \\
\text { freedom }\end{array}$ & \multicolumn{1}{c}{$\mathrm{F}$} & p-value \\
\hline $\mathrm{CHCl}_{3}$ & 3 & 32.04 & $<0.001$ \\
tank & 1 & 3.16 & 0.08 \\
season & 3 & 0.83 & 0.48 \\
tank * season & & & \\
\hline $\mathrm{CHCl}_{2} \mathrm{Br}$ & 3 & 21.04 & $<0.001$ \\
tank & 1 & 2.33 & 0.13 \\
season & 3 & 0.21 & 0.89 \\
tank * season & & & \\
\hline RANKS of $\mathrm{CHClBr}$ & & & \\
tank & 3 & 97.80 & $<0.001$ \\
season & 1 & 0.45 & 0.50 \\
tank * season & 3 & 0.25 & 0.86 \\
\hline Design: Intercept+tank+season+tank * season; $\mathrm{df}_{\text {Error }}=135$
\end{tabular}

Pair-wise comparison (Table 5) by the Bonferroni test indicated statistical significant differences between the Galatsi 1, Galatsi 2 and Menidi, Aspropyrgos $\mathrm{CHCl}_{3}, \mathrm{CHCl}_{2} \mathrm{Br}$ concentrations. The first two tanks, which are provided by untreated water both from Marathon and Mornos reservoirs, presented lower mean concentration values for $\mathrm{CHCl}_{3}$ than the other two tanks which are provided by untreated water exclusively from Mornos. The results are exactly the opposite for the mean $\mathrm{CHCl}_{2} \mathrm{Br}$ concentrations and the mean ranks of the $\mathrm{CHClBr}_{2}$ concentrations. The mean rank of the $\mathrm{CHClBr}_{2}$ concentration was statistical significantly lower in the Aspropyrgos tank than each one of the other tanks.

Figures 1-3 present the estimated marginal means, per tank, of $\mathrm{CHCl}_{3}, \mathrm{CHCl}_{2} \mathrm{Br}$ and the ranks of $\mathrm{CHClBr}_{2}$ respectively.

Significant positive correlations were found between the three THMs in each one of the treated water tanks (Table 6). The magnitude of the correlations was moderate to high. Multivariate analysis of variance (MANOVA) could be used as a statistical technique for assessing group differences across dependent scale variables simultaneously, based on the set of categorical variables (season, tank) acting as independent variables (factors). This procedure tests the null hypotheses about the effects of factor variables on the means of various groupings of a joint distribution of dependent variables. In other words, MANOVA is used to assess whether an overall difference exists between groups. However, the assumptions for MANOVA are stricter than those for the ANOVA. Due to violation of the multivariate homogeneity, the MANOVA procedure was not used. 
Table 6 also presents the results for the Spearman rank correlation between the THMs and other chemical parameters such as total organic carbon (TOC), chlorine dose $(\mathrm{dCl})$, bromide $(\mathrm{Br}), \mathrm{pH}$ and temperature (Temp). There are differences between observed significant correlations between THMs and the other parameters for various tanks.

The small temperature range might be the most important cause of low seasonality through years 20042006. The range 8-16 ${ }^{\circ} \mathrm{C}$ of raw water temperature which is the result of a three-year weather with mild winters and hot summers made impossible a seasonal variation such as one of Quebec, Canada (Rodriguez and Serodes, 2001). Obviously, the effect of solar rays on chlorine evaporation drives WTP operators to increase pre and postchlorination during summer months. However, neither small fluctuations in temperature nor fluctuations in chlorine dosage indicate high differences in THM levels.

Table 5. Pairwise Comparisons

\begin{tabular}{|c|c|c|c|c|c|}
\hline & (I) tank & (J) tank & $\begin{array}{c}\text { Mean } \\
\text { Difference } \\
(\mathrm{I}-\mathrm{J})\end{array}$ & $\begin{array}{l}\text { Std. } \\
\text { Error }\end{array}$ & $p$-value ${ }^{a}$ \\
\hline \multirow[t]{12}{*}{$\mathrm{CHCl}_{3}$} & \multirow[t]{3}{*}{ Galatsi 1} & Galatsi 2 & -0.930 & 0.660 & 0.966 \\
\hline & & Menidi & $-4.555^{\star}$ & 0.647 & $<0.001$ \\
\hline & & Aspropyrgos & $-5.301^{*}$ & 0.654 & $<0.001$ \\
\hline & \multirow[t]{3}{*}{ Galatsi 2} & Galatsi 1 & 0.930 & 0.660 & 0.966 \\
\hline & & Menidi & $-3.625^{*}$ & 0.660 & $<0.001$ \\
\hline & & Aspropyrgos & $-4.370^{*}$ & 0.667 & $<0.001$ \\
\hline & \multirow[t]{3}{*}{ Menidi } & Galatsi 1 & $4.555^{\star}$ & 0.647 & $<0.001$ \\
\hline & & Galatsi 2 & $3.625^{\star}$ & 0.660 & $<0.001$ \\
\hline & & Aspropyrgos & -0.746 & 0.654 & 1 \\
\hline & \multirow[t]{3}{*}{ Aspropyrgos } & Galatsi 1 & $5.301^{*}$ & 0.654 & $<0.001$ \\
\hline & & Galatsi 2 & $4.370^{\star}$ & 0.667 & $<0.001$ \\
\hline & & Menidi 2 & 0.746 & 0.654 & 1 \\
\hline \multirow[t]{12}{*}{$\mathrm{CHCl}_{2} \mathrm{Br}$} & \multirow[t]{3}{*}{ Galatsi 1} & Galatsi 2 & -0.219 & 0.272 & 1 \\
\hline & & Menidi & $1.254^{*}$ & 0.266 & $<0.001$ \\
\hline & & Aspropyrgos & $1.536^{*}$ & 0.269 & $<0.001$ \\
\hline & \multirow[t]{3}{*}{ Galatsi 2} & Galatsi 1 & 0.219 & 0.272 & 1 \\
\hline & & Menidi & $1.473^{\star}$ & 0.272 & $<0.001$ \\
\hline & & Aspropyrgos & $1.754^{\star}$ & 0.275 & $<0.001$ \\
\hline & \multirow[t]{3}{*}{ Menidi } & Galatsi 1 & $-1.254^{*}$ & 0.266 & $<0.001$ \\
\hline & & Galatsi 2 & $-1.473^{*}$ & 0.272 & $<0.001$ \\
\hline & & Aspropyrgos & 0.281 & 0.269 & 1 \\
\hline & \multirow[t]{3}{*}{ Aspropyrgos } & Galatsi 1 & $-1.536^{\star}$ & 0.269 & $<0.001$ \\
\hline & & Galatsi 2 & $-1.754^{\star}$ & 0.275 & $<0.001$ \\
\hline & & Menidi & -0.281 & 0.269 & 1 \\
\hline \multirow[t]{12}{*}{ Ranks of $\mathrm{CHClBr}_{2}$} & \multirow[t]{3}{*}{ Galatsi 1} & Galatsi 2 & 3.684 & 5.694 & 1 \\
\hline & & Menidi & $56.844^{*}$ & 5.579 & $<0.001$ \\
\hline & & Aspropyrgos & $80.262^{*}$ & 5.642 & $<0.001$ \\
\hline & \multirow[t]{3}{*}{ Galatsi 2} & Galatsi 1 & -3.684 & 5.694 & 1 \\
\hline & & Menidi & $53.160 *$ & 5.694 & $<0.001$ \\
\hline & & Aspropyrgos & $76.578^{\star}$ & 5.756 & $<0.001$ \\
\hline & \multirow[t]{3}{*}{ Menidi } & Galatsi 1 & $-56.844^{\star}$ & 5.579 & $<0.001$ \\
\hline & & Galatsi 2 & $-53.160^{\star}$ & 5.694 & $<0.001$ \\
\hline & & Aspropyrgos & $23.418^{\star}$ & 5.642 & $<0.001$ \\
\hline & \multirow[t]{3}{*}{ Aspropyrgos } & Galatsi 1 & $-80.262^{*}$ & 5.642 & $<0.001$ \\
\hline & & Galatsi 2 & $-76.578^{*}$ & 5.756 & $<0.001$ \\
\hline & & Menidi & $-23.418^{*}$ & 5.642 & $<0.001$ \\
\hline
\end{tabular}

Based on estimated marginal means

* The mean difference is significant at the 0.05 level.

a Adjustment for multiple comparisons: Bonferroni. 


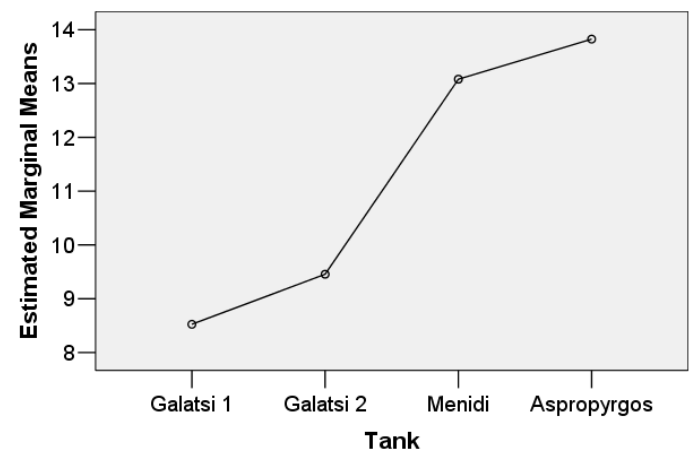

Figure 1. Estimated marginal means of $\mathrm{CHCl}_{3}$

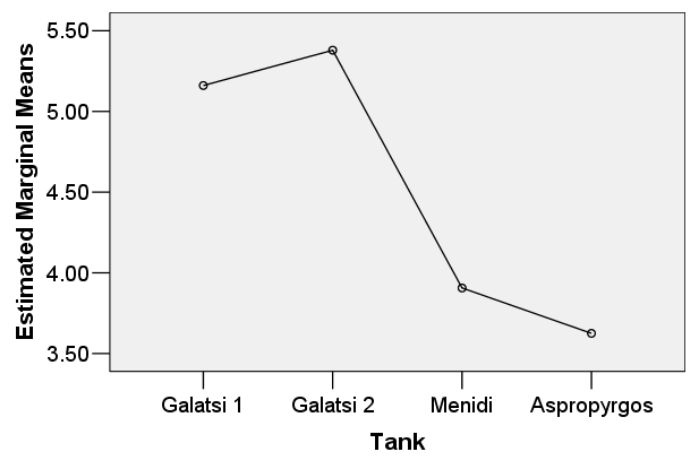

Figure 2. Estimated marginal means of $\mathrm{CHCl}_{2} \mathrm{Br}$

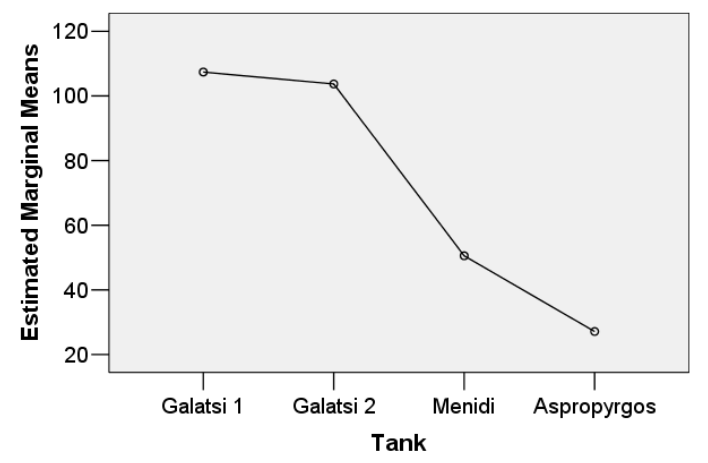

Figure 3. Estimated marginal means of ranks of $\mathrm{CHClBr}_{2}$

It is obvious that prechlorination dosage is the primary cause of THM formation, because postchlorination is applied after processes such as flocculation with alum sulfate and sand filtration on half-processed water with physical parameters modified from those of initial raw water e.g. $\mathrm{pH}, \mathrm{TOC}$, reducing materials such as $\mathrm{Fe}, \mathrm{Mn}, \mathrm{NH}_{3}$ that increase chlorine demand. Data from prechlorination dosage are not available.

Correlation of low significance between TOC and THM species is in accordance with surveys of Arora et al. (1997). However, larger TOC fluctuations that existed during 1990-1996 might reveal a greater correlation (Golfinopoulos and Arhonditsis, 2002).

Past bibliography proved that there is a bromine substitution of chlorine in $\mathrm{HClO}$. The presence of $\mathrm{Br}^{-}$ during the chlorination process affects both the formation and distribution of THMs (Mok et al., 2005). At low concentrations, $1 \times 10^{-7} \mathrm{~mol} \mathrm{~L}^{-1}$, little effect was observed. At the higher concentrations $1 \times 10^{-5} \mathrm{~mol} \mathrm{~L}^{-1}$ till $1 \times 10^{-4} \mathrm{~mol} \mathrm{~L}^{-1}$ concentration of the four THMs separately changed in favour of the three brominated THMs (Bofill et al., 1981). Raw water processed by Galatsi 1 and 2 WTPs had mean bromide concentration equal to $22 \mathrm{\mu g} \mathrm{L}^{-1}\left(0.28 \times 10^{-6} \mathrm{~mol} \mathrm{~L}^{-1}\right)$ whereas Aspropyrgos and Menidi raw water had lower mean bromide concentration equal to $7 \mathrm{\mu g} \mathrm{L}^{-1}\left(0.88 \times 10^{-7} \mathrm{~mol} \mathrm{~L}^{-1}\right)$. This competition between chlorine and bromide to attack organic content and join carbon might explain the mean performance of the THMs species in the treated water tanks (Figure 3); the presence of bromides prevents $\mathrm{CHCl}_{3}$ formation in favour of $\mathrm{CHCl}_{2} \mathrm{Br}$ and $\mathrm{CHClBr}_{2}$ production in Galatsi WTP. A statistically significant negative correlation between $\mathrm{CHCl}_{3}$ and bromides was observed for the Galatsi 2 tank (Table 6). 
Table 6. Spearman's rho Correlation coefficient between $\mathrm{CHCl}_{3}, \mathrm{CHCl}_{2} \mathrm{Br}, \mathrm{CHClBr}_{2}$, total organic carbon (TOC), chlorine dose (dCl), bromide ( $\mathrm{Br}), \mathrm{pH}$ and temperature (Temp.)

\begin{tabular}{|c|c|c|c|c|c|c|c|c|c|}
\hline Tank & & $\mathrm{CHCl}_{3}$ & $\mathrm{CHCl}_{2} \mathrm{Br}$ & $\mathrm{CHClBr}_{2}$ & TOC & $\mathrm{DCl}$ & $\mathrm{Br}^{-}$ & $\mathrm{pH}$ & Temp. \\
\hline \multirow{8}{*}{ 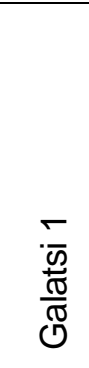 } & $\mathrm{CHCl}_{3}$ & 1 & & & & & & & \\
\hline & $\mathrm{CHCl}_{2} \mathrm{Br}$ & $0.496^{\star \star}$ & 1 & & & & & & \\
\hline & $\mathrm{CHClBr}_{2}$ & 0.098 & $0.641^{\star *}$ & 1 & & & & & \\
\hline & TOC & $0.418^{*}$ & 0.307 & 0.214 & 1 & & & & \\
\hline & $\mathrm{dCl}$ & $-0.418^{\star}$ & $-0.343^{*}$ & -0.146 & -0.213 & 1 & & & \\
\hline & $\mathrm{Br}^{-}$ & -0.161 & -0.041 & 0.137 & 0.242 & $0.499^{* *}$ & 1 & & \\
\hline & $\mathrm{pH}$ & 0.299 & 0 & -0.14 & 0.072 & 0.088 & 0.245 & 1 & \\
\hline & Temp. & 0.067 & 0.034 & 0.208 & -0.106 & 0.204 & $-0.374^{*}$ & -0.294 & 1 \\
\hline \multirow{8}{*}{$\frac{N}{\frac{N}{\pi}}$} & $\mathrm{CHCl}_{3}$ & 1 & & & & & & & \\
\hline & $\mathrm{CHCl}_{2} \mathrm{Br}$ & $0.653^{\star \star}$ & 1 & & & & & & \\
\hline & $\mathrm{CHClBr}_{2}$ & $0.387^{*}$ & $0.663^{\star *}$ & 1 & & & & & \\
\hline & TOC & 0.165 & $0.406^{*}$ & 0.23 & 1 & & & & \\
\hline & $\mathrm{dCl}$ & -0.261 & $-0.408^{*}$ & -0.166 & -0.285 & 1 & & & \\
\hline & $\mathrm{Br}^{-}$ & $-0.377^{\star}$ & -0.1 & 0.163 & 0.16 & 0.329 & 1 & & \\
\hline & $\mathrm{pH}$ & 0.041 & -0.168 & $-0.426^{*}$ & -0.048 & 0.198 & -0.258 & 1 & \\
\hline & Temp. & $0.364^{*}$ & 0.243 & 0.297 & -0.146 & 0.191 & -0.285 & -0.248 & 1 \\
\hline \multirow{8}{*}{ 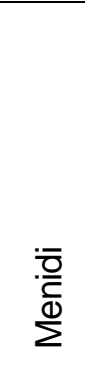 } & $\mathrm{CHCl}_{3}$ & 1 & & & & & & & \\
\hline & $\mathrm{CHCl}_{2} \mathrm{Br}$ & $0.562^{\star \star}$ & 1 & & & & & & \\
\hline & $\mathrm{CHClBr}_{2}$ & $0.552^{\star \star}$ & $0.590^{* *}$ & 1 & & & & & \\
\hline & TOC & -0.015 & 0.097 & -0.024 & 1 & & & & \\
\hline & $\mathrm{dCl}$ & 0.035 & 0.206 & -0.260 & $0.470^{*}$ & 1 & & & \\
\hline & $\mathrm{Br}^{-}$ & -0.170 & -0.083 & -0.042 & -0.004 & 0.266 & 1 & & \\
\hline & $\mathrm{pH}$ & -0.275 & -0.166 & $-0.417^{*}$ & 0.294 & $0.508^{\star *}$ & $0.613^{\star \star}$ & 1 & \\
\hline & Temp. & 0.195 & 0.103 & -0.135 & 0.033 & $0.382^{*}$ & $-0.360^{*}$ & -0.037 & 1 \\
\hline \multirow{8}{*}{$\begin{array}{l}\text { ஜ } \\
\text { on } \\
\frac{0}{2} \\
\frac{0}{0} \\
\frac{0}{0} \\
\frac{1}{4}\end{array}$} & $\mathrm{CHCl}_{3}$ & 1 & & & & & & & \\
\hline & $\mathrm{CHCl}_{2} \mathrm{Br}$ & $0.560^{\star \star}$ & 1 & & & & & & \\
\hline & $\mathrm{CHClBr}_{2}$ & $0.368^{\star}$ & $0.728^{* *}$ & 1 & & & & & \\
\hline & TOC & -0.114 & -0.174 & -0.047 & 1 & & & & \\
\hline & $\mathrm{dCl}$ & 0.31 & 0.087 & 0.138 & 0.269 & 1 & & & \\
\hline & $\mathrm{Br}^{-}$ & -0.105 & -0.044 & -0.161 & 0 & 0.147 & 1 & & \\
\hline & $\mathrm{pH}$ & -0.016 & $-0.335^{\star}$ & $-0.376^{\star}$ & 0.1 & 0.304 & $0.378^{\star}$ & 1 & \\
\hline & Temp. & $0.428^{*}$ & 0.241 & 0.290 & -0.006 & $0.429 *$ & -0.266 & -0.146 & 1 \\
\hline
\end{tabular}

${ }^{\star *}$ Correlation is significant at the 0.01 level (2-tailed).

${ }^{*}$ Correlation is significant at the 0.05 level (2-tailed).

\section{CONCLUSIONS}

It is obvious that THMs levels depend on operational parameters such as chlorine dosage and raw water characteristics such as bromide concentration or $\mathrm{pH}$. However, THMs levels of chlorinated raw water from the same aquifer Mornos reservoir differ to Menidi WTP from Aspropyrgos. So, the effects of every WTP are important for the sum of THMs as well as the concentration of each one of the three present THM species $\left(\mathrm{CHBr}_{3}\right.$ is almost absent).

Whenever bromide is present, it competes with chlorine to attack raw water organic content. As a result, $\mathrm{CHCl}_{3}$ increase means $\mathrm{CHCl}_{2} \mathrm{Br}$ and $\mathrm{CHClBr}_{2}$ decrease and the opposite. On the contrary, plants that process Mornos reservoir water with low bromide levels (namely Aspropyrgos and Menidi) form the three species with a relatively stable ratio because there is a clearly positive correlation between the 3 species and increase of one of them predicts a possible proportional increase of the two others.

Although there is a higher chlorine dosage application during summer months in order to compensate losses due to dechlorination from solar rays, seasonality was not significant, probably because of relatively low temperature fluctuations. Residual chlorine of $0.20 \mathrm{ppm}$ must remain along the distribution system so as to maintain an acceptable microbiological water quality while minimising THM formation. 


\section{ACKNOWLEDGEMENTS}

The authors would like to thank all the staff of the Quality Control Department of EYDAP SA. Special thanks to Mr. P. Tzoumerkas, former Director of the Quality Division of EYDAP SA and Mr. L. Kousouris, former Supervisor of the Quality Control Department of EYDAP SA.

\section{REFERENCES}

Arora H., LeChevalier M., Dixon K., (1997), DBP occurrence survey, J. AWWA, 89(6), 60-68.

Bofill C.C., Cooper W.J., Cordal E., Meyer L.M (1981) Quantitative effects of Bromine on the formation and distribution of trihalomethanes in groundwater with a high organic content, In: Water Chlorination, Environmental Impacts and Heath Effects, Ann Arbor Science, 1981, 285- 296.

Cancho B. and Ventura F. (2005) Optimisation of methods for the determination of DBPs,, Global NEST J., 7(1), 72-94.

Dore M., De Laat J., Goichon J. and Merlet N. (1982) Reactivity of halogens with aqueous micropollutants: a mechanism for the formation of trihalomethanes, J. AWWA, 74(2), 103-107.

Gang D., Segar R., Clevenger Th., Banerji Sh, (2001) "Prediction of TTHM and HAA9 Based on the Chlorine Demand", American Water Works Association (AWWA) - Water Quality Technology (WQTC) Proceedings - November 11-14, 2001. Nashville, TN.

Golfinopoulos S.and Arhonditsis G. (2002) Multiple regression models: A methodology for evaluating trihalomethane concentrations in drinking water from raw water characteristics, Chemosphere, 47, 10071018.

Golfinopoulos S. and Nikolaou A.. (2005) Formation of DBPs in the drinking water of Athens, Greece: A ten year study, Global NEST J., 7(1), 106-118.

Helsel D.R. and Hirsch R.M., (2002). Statistical Methods in Water Resources. Techniques of Water Resources Investigations, Book 4, chapter A3. United States Geological Survey.

Mok K.M., Fan X.J., Wong H., (2005), Modelling bromide effects on the speciation of trihalomethanes formation in chlorinated drinking water, Global NEST J., 7(1), 1-16.

Nikolaou A.D., Kostopoulou M.N. and Lekkas T.D., (1999) Organic By-Products of drinking water Chlorination, Global NEST: the Int. J., 1(3), 143-156].

Nikolaou A.D., Golfinopoulos S.K., Kostopoulou M.N. and Lekkas T.D. (2001) Investigation of the behaviour of haloketones in water samples, Chemosphere, 44, 907-912.

Rodriguez M. and Serodes J.-B. (2001) Spatial and temporal evolution of trihalomethanes in three water distribution systems, Wat. Res., 35(6), 1572-1586.

Singer and Chang (1989) Correlations Between Trihalomethanes And Total Organic Halides Formed During Water Treatment, J. AWWA, 81(8), 61-65.

Symons J., Krasner S., Simms L. and Sclimenti M. (1993) Measurement of THM and Precursor Concentrations Revisited: The Effect of Bromide Ion, J. AWWA, 85(1), 51-62. 